\title{
Early British students of modern foraminifera: Carpenter and Williamson
}

\author{
JOHN W. MURRAY \\ National Oceanography Centre Southampton, University of Southampton Waterfront Campus, European Way, Southampton SO14 3ZH, UK \\ (e-mail: jwm1@noc.soton.ac.uk)
}

\begin{abstract}
Most early workers in the field of foraminifera were learned gentlemen with great curiosity and broad interests who pursued microscopy as a hobby. Through their careful observations, Carpenter and Williamson laid the foundations of our understanding of morphology, growth plans and wall structure. They made their observations at a time when the zoological affinities of foraminifera were still under discussion. Because of the variability of form they took a broad view of taxonomic relationships, especially of genera and species, which strongly influenced later workers. J. Micropalaeontol. 31(2): 159-167, July 2012.
\end{abstract}

KEYWORDS: $\quad$ benthic foraminifera, growth plans, wall structure, carbonate sediments

\section{INTRODUCTION}

Science evolves through the progression of ideas and hypotheses proposed by earlier workers. The aim of this paper is to throw some light on the contributions of early studies to the understanding of foraminifera with particular emphasis on the contributions of the two English polymaths, William Benjamin Carpenter (1813-85) and William Crawford Williamson (1816-95). It was not until the twentieth century that foraminifera became economically significant. All studies prior to that were carried out by naturalists curious to learn more of the relationships both of different types of foraminifera and especially with other taxonomic groups.

\section{BACKGROUND TO NINETEENTH CENTURY RESEARCH ON FORAMINIFERA}

The nineteenth century was a period of major social and technological change. When evaluating the scientific contributions of early students of micropalaeontology it is necessary to consider the limitations under which they worked. Two major constraints on scientific thinking and activity were the religious-based education and the limited technology available.

Education was largely under the control of the church and teaching religion and classical languages was considered to be much more important than nowadays. From 1859 Darwin's On the Origin of Species profoundly affected religious and scientific thoughts.

Natural science (including microscopy) was primarily a hobby interest of gentlemen. The quality of microscope optics was not as good as that now available and most instruments were not suitable for stereoscopic imagery. Apart from microscopes the basic equipment included candles, spirit lamps, gas lamps or sunlight as a light source; glass slides and cover glasses, and Canada balsam as a mounting medium (d'Orbigny mounted material on paper strips; Heron-Allen, 1917). By the latter part of the nineteenth century wooden slides were made to hold material from the Challenger expedition. There was no electronic equipment, such as scanning electron microscopes (SEM), computers or photocopiers (all introduced in the 1960s). In Britain, working away from London meant limited access to literature (as noted by Williamson, 1858). Prior to the opening of the Natural History Museum, London in 1881, there was no satisfactory provision to house slide collections and those of older workers, such as Montagu
(1803; 1808), were lost to science. Illustration was by means of drawing or water colour sketches made either freehand or using camera lucida. The latter resulted in superior illustrations to those produced by photography in the twentieth century and more realistic than SEM images at low magnification.

It was during the nineteenth century that the first academic positions in the broad subject of natural history were established and both Williamson and Carpenter were pioneers in their fields. There were fewer journals and scientific societies and organizations such as the Ray Society and even the Royal Society published papers on foraminifera. The Royal Society has the original hand-written letters from referees (Darwin and Huxley) of some of Carpenter's papers: 1856a, RR3.37-39; 1856b, RR.3.40, 41, 43. In each case the letter is brief and basically says that the paper is suitable for publication - no boxes to tick, no shades of acceptance, and no detailed comments on required revisions! There were general journals, such as the Annals and Magazine of Natural History, and those of regional literary and philosophical societies (e.g. in Manchester, Liverpool, Leicester). New societies with a focus on microscopy emerged in the 1850s (Royal Microscopical Society, Queckett Microscopical Club). The British Association for the Advancement of Science (established 1831) was probably the most active focus for scientific discussion and the introduction of significant new ideas. It was famed for the 1860 debate on Darwin's evolutionary ideas between Thomas Henry Huxley and Bishop Samuel Wilberforce.

\section{FORAMINIFERA AS OBJECTS OF CURIOSITY}

Most of the nineteenth century British students of foraminifera came from a medical background (Williamson, Carpenter, Parker and Brady). Foraminifera were regarded as curiosities that were of interest because they were aesthetically attractive, could be collected in large numbers and were apparently simple organisms. Also, they had no obvious value except as being part of 'natural history'. Their study seemed to be a gentle diversion from the more serious matters of illness and death.

\section{THE KEY CONTRIBUTORS}

In Britain the main contributions were made by Carpenter, Williamson and Henry Bowman Brady (Jones, 1994). In France: Alcide d'Orbigny (1802-57, see Heron-Allen, 1917; Le Calvez, 


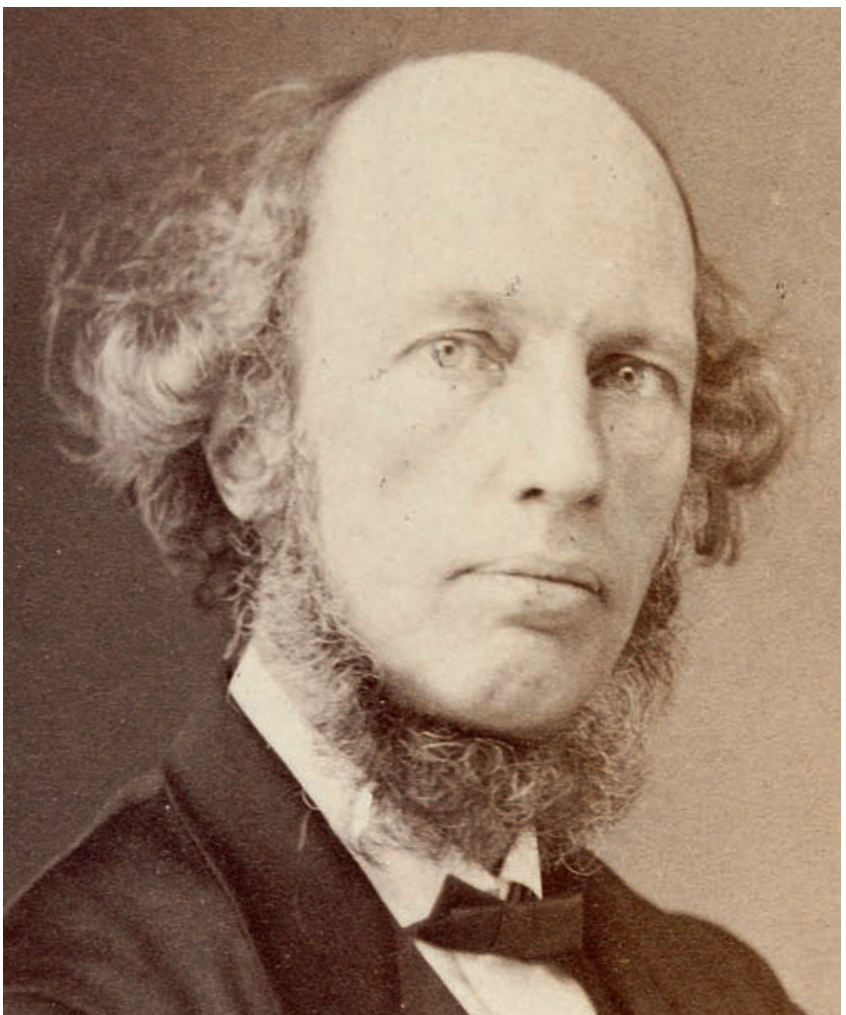

(a)

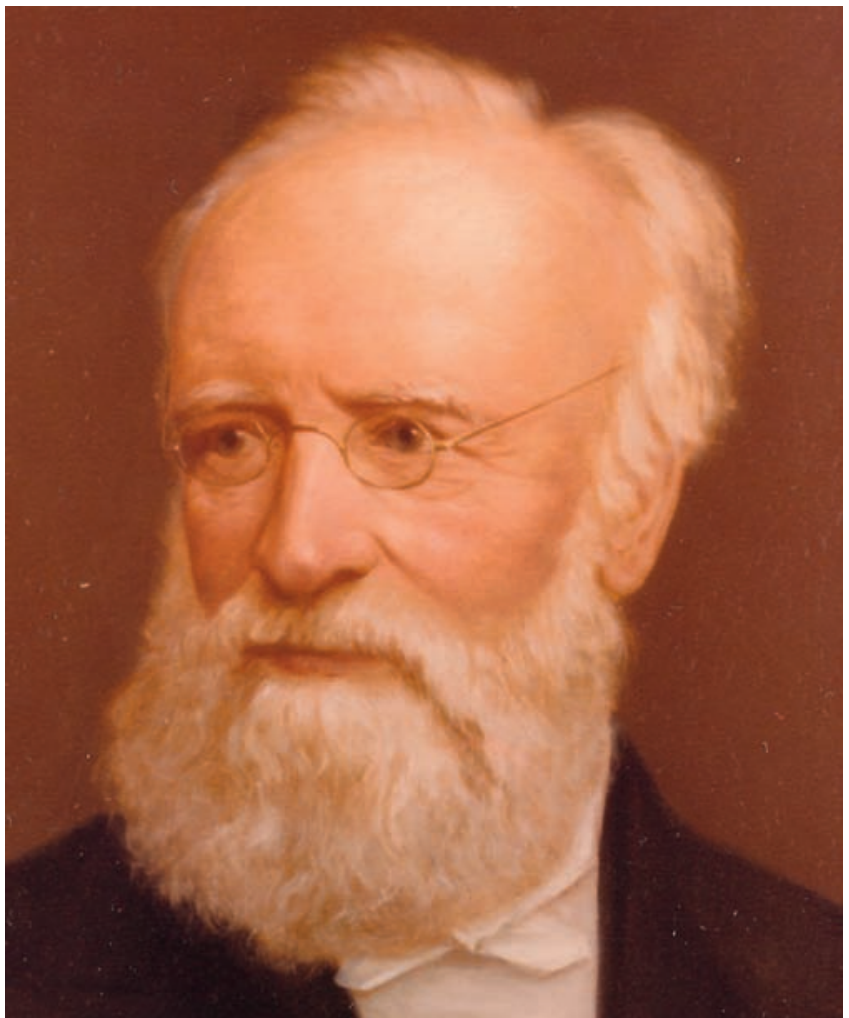

(b)

Fig. 1. (a) W. B. Carpenter (courtesy of the Royal Society); (b) W. C. Williamson. (portrait by H. Brothers, Botany Department; courtesy of the University Librarian and Director, The John Rylands University Library, The University of Manchester).

1974), Fritz Dujardin (Corliss, 1978); in Germany: Ehrenberg (regarded by Corliss, 1978, as the founder of protozoology - but mainly on ciliates) and Johann Ludwig Rhumbler (1864-1939, Bartenstein, 1964). D’Orbigny and Ehrenberg described species from Recent and fossil deposits whereas Dujardin and Rhumbler were concerned mainly with observations of living foraminifera, although Rhumbler also contributed to taxonomy at higher levels as well as erecting 38 genera. In a brief review Hiltermann (1958) published portraits of 36 early micropalaeontologists (not all involved with foraminifera). A list of other British contributors is given in Appendix A.

\section{WILLIAMSON}

William Crawford Williamson (1816-1895) (Fig. 1b) was born into a family where the study of natural history was a part of daily life: his father was the first curator of the Scarborough Natural History Museum and the pioneering geologist William Smith lived in the Williamson household for two years. After completing a medical degree at University College London, in 1841, Williamson went to Manchester to practise as a GP and a surgeon. In 1851 he was appointed Professor of Natural History at Owen's College where he taught Botany, Zoology and Geology as well as continuing his medical work. In his 1858 work he noted two major problems: being a provincial naturalist without ready access to the current literature and 'Equally unfavourable to sustained research is the life of a medical man engaged in the incessant duties of general practice' ( $\mathrm{p}$. xx). It is, therefore, remarkable that his research spanned palaeobotany, coal petrology, palaeontology and stratigraphy of the Jurassic, and the histology of teeth (Murray, 1981). His hobby was water colour painting. His autobiography (see Watson \& Thomas, 1985) makes fascinating reading. Owen's College was a forerunner of the University of Manchester and the geosciences building is named in honour of Williamson.

Williamson's foraminiferal studies started around 1843 (first publication, Williamson, 1847) and peaked in 1858, with only two short papers in later years (Williamson, 1865; 1876; see the bibliography for a complete list of his works on foraminifera). His interest in the group was stimulated when he read that Ehrenberg (1838) had discovered that chalk was made of little shells. But at that time Williamson had no microscope (Williamson, in Watson \& Thomas, 1985, p. 95). Although taxonomy was not his strength, he is probably best remembered for his taxonomic papers on Lagena (Williamson, 1848a) and British Recent foraminifera (1858, for which he almost certainly prepared the colour drawings) but his contributions to our knowledge of foraminifera covered a broad spectrum. He was the first person to devise a flotation method for separating foraminifera from sediment (Watson \& Thomas, 1985, p. 110). He was a perceptive observer with a keen eye for detail and a very enquiring mind. He always considered the functional relationships between hard and soft parts and this is most clearly demonstrated by his writings on wall structure and the manner of its secretion (Williamson, 1848b; $1851 ; 1853 ; 1876)$. Williamson used mainly dried samples and for 

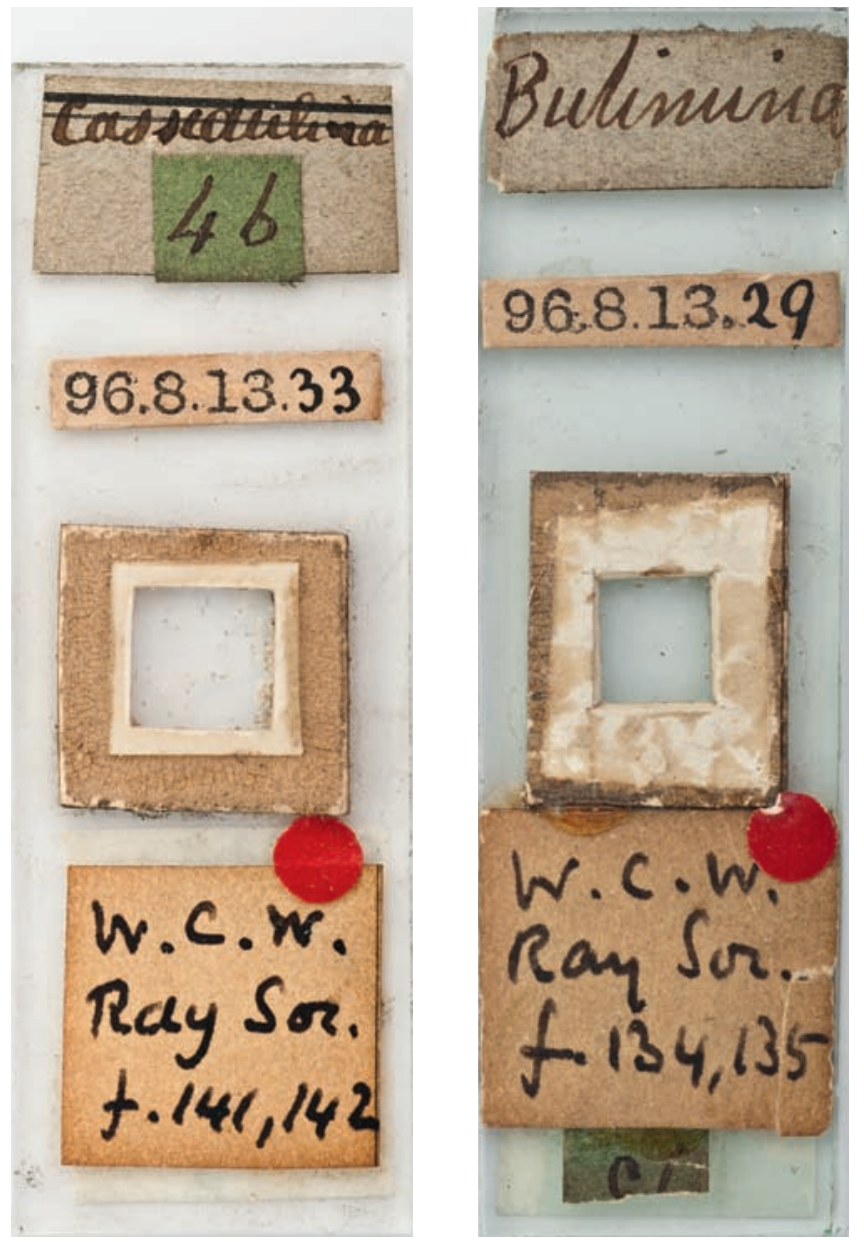

Fig. 2. Williamson slides in the Natural History Museum, London. Cassidulina and Bulimina (figs 141, 142 and 134, 135 respectively, in Williamson, 1858). The slide is glass and the cover slip is raised so that the specimens are dry-mounted in the space between the two.

all species he made strew slides of syntypes (see Fig. 2 for examples of his slides). He criticized Ehrenberg for exclusively making balsam mounts so that he looked through specimens rather than at them (Williamson, 1848b).

Williamson was a contemporary of Darwin (1809-82). The two corresponded and Darwin supplied Williamson with material from S America (Williamson, 1847, p. 66). He worked at a time when there was still great uncertainty about the relationships between organisms and the taxonomic affinities of foraminifera were no exception. There was also uncertainty over what constituted a species and Williamson's work preceded Darwin's On the Origin of Species, which was published in 1859.

\section{CARPENTER}

William Benjamin Carpenter (Fig. 1a) was born in Exeter in 1813 but spent most of his childhood in Bristol. When he was 15 (1828) he went to Bristol Medical School, then moved to University College London in 1834 and Edinburgh in 1835, graduating $\mathrm{MD}$ in 1839 . He bought a microscope with $£ 30$ won for a graduation essay. In 1837, he commenced a lectureship in medical jurisprudence in the Bristol Medical School. From 1844 to 1847 he was Fullerian Professor of Physiology at the Royal Institution, London, then Swineyan Lecturer in Geology at the British Museum (1847), Professor of Medical Jurisprudence at University College London in 1849 and finally Registrar at the University of London from 1856 to 1879 (Murray, 1981).

Carpenter was a man of considerable influence, being a VicePresident of the Royal Society (FRS 1844, Royal Medal 1861). Through his contacts with the Admiralty he obtained the use of the steam frigate HMS Lightning in the summer of 1868 for Professor Wyville Thomson to sample the seafloor between the Faeroes and Shetland. This was to test the theory put forward by Edward Forbes that life was absent at depths greater than 300 fathoms $(\sim 550 \mathrm{~m})$. In the event, organisms (including foraminifera) were retrieved from 600 fathoms thus disproving Forbes' theory. Following similar expeditions led by Wyville Thomson on HMS Porcupine (1869, 1870) and HMS Shearwater (1871) the techniques of depth sounding and dredging were well established as oceanographic tools. Wyville Thomson and Carpenter were able to persuade the Admiralty and the Royal Society to organize the first global oceanographic expedition on HMS Challenger. The application for funds in 1871 was approved in April 1872 and the cruise commenced in December 1872. Corfield (2004) suggests that there were three reasons for the expedition: prestige for Great Britain, having the ability to organize such a major affair because of possessing the largest navy in the world, and to choose between god and science by testing the new theory of descent (evolution) advanced by Darwin in 1859. Wyville Thomson was chosen to lead the expedition, much to the chagrin of Carpenter, and the friendship between the two men cooled.

With his newly acquired microscope in 1839 Carpenter developed an interest in foraminifera and published numerous papers from 1849 to 1900 (see the bibliography for a complete list of his works on foraminifera). His classic work in the Ray Society (Carpenter, 1862) was intended as an introduction to Williamson's (1858) monograph on Recent forms. His particular interest was the morphology and detailed structure of larger foraminifera in which he used the thin-section method pioneered by Williamson (Watson \& Thomas, 1985, p. 109). He had access to the Challenger collection. Some of his slides are stored in Exeter Museum (Murray, 1981; Murray \& Taplin, 1984) and others in the Natural History Museum, London (see Fig. 3 for examples of his slides). He also worked on material from several other early oceanographic cruises (Carpenter, 1868 - Lightning; 1877 Valorus; Carpenter et al., 1870 - Porcupine). He published a popular account of microscopy running to six editions (e.g. Carpenter, 1875a; 1881), medicine and echinoderms. He corresponded with Darwin (letters 802, 813 on Chilean tuffa).

His 1862 work was published with the collaboration of Parker and Jones. He notes that they supplied him with material and discussed ideas but that it was 'more conducive both to unity of design and to completeness of effect' for him to write the entire work (Carpenter, 1862, p. vi). Whereas he had mainly studied material from tropical Australia and Philippine seas, they had knowledge of a wide range of genera from modern and fossil deposits.

\section{TAXONOMIC AFFINITIES OF FORAMINIFERA}

In this review no attempt is made to deal with the development of the classification of foraminifera as that has admirably been covered in detail by Cifelli (1990). However, in the early nineteenth 

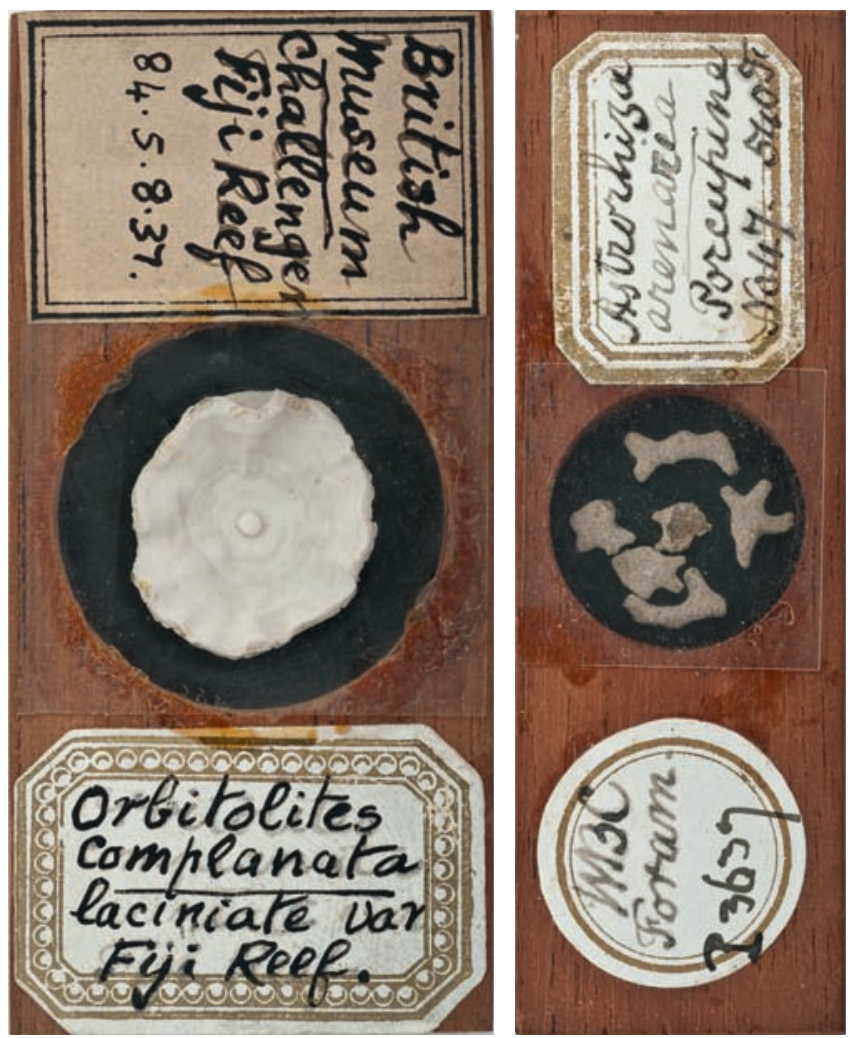

Fig. 3. Carpenter slides in the Natural History Museum, London. Astrorhiza arenaria Norman (Porcupine cruise) and Orbitolites (Challenger sample from Fiji). The slides are wood with a paper base and a glass cover slip.

century there was still great uncertainty about the relationships between organisms and the taxonomic affinities of foraminifera were no exception. There were three main views regarding the affinities of foraminifera: cephalopods (d'Orbigny, 1826); rhizopods (term introduced by Dujardin, 1835b); bryozoa (Ehrenberg, 1838). Little was known of the soft parts. Probably the first observation of pseudopods was by d'Orbigny father and son in 1819 using a hand lens (they did not have a microscope) but they regarded the pseudopods as tentacles as they considered foraminifera to be cephalopods (Heron-Allen, 1917). Later, Dujardin (1835a-d) published a series of short notes in which he demonstrated that foraminifera were not cephalopods as they have pseudopods (his 'filaments'); he introduced the term 'sarcode' for the protoplasmic body. In 1847 Gervais noted that they are simple organisms, very different from molluscs and bryozoa. However, the significance of these observations was not immediately realized partly because other workers looked at dried modern forms and claimed to recognize metazoan features. Furthermore, through the exchange of sediment samples from different seas and oceans, as well as from fossil deposits, contemporary workers using early microscopes must have been bewildered by the diversity of microscopic organisms in general.

It is not clear when Williamson first saw pseudopodia but he frequently referred to them in his papers from 1848 b onwards. $\mathrm{He}$ also mentioned observations by other workers: Forbes had seen 'moniliform strings of granular substance' extruded from the aperture of living nodosariids (Williamson, 1851, p. 110); Ehrenberg (1839 [1840]) saw bundles of pseudopodia extending from the umbilical regions of material from Germany (Williamson, 1848b, p. 170). However, Williamson described and illustrated the protoplasmic contents of the dissolved shells of Polystomella crispa (= Elphidium crispum (Linné); Williamson, 1848b, p. 165, figs 6, 7). Nevertheless, in 1847 and 1848a he concluded that foraminifera were bryozoans because he followed Ehrenberg's interpretation that the foraminifera had an internal digestive cavity. In 1851 Williamson wrote that the soft parts were probably a 'gelatinous net-work' and that there was no alimentary canal as supposed by Ehrenberg (Williamson, 1851, p. 126). In 1853 he was considering the possibility that they might be calcareous sponges but he cautioned against reaching a firm decision until more facts were known (Williamson, 1853) and, in 1858, merely recorded that they were rhizopods (Williamson, 1858). Later in the 1860 s he recalled

Remembering how I had been misled in my earliest researches amongst the Foraminifera by relying upon the authority of M Ehrenberg, I determined not to look at the writings of any other observer until I had studied every specimen in my cabinet, and arrived at my own conclusions as to what they taught (Williamson, in Watson \& Thomas, 1985, p. 201).

\section{IMPORTANCE OF TEST WALL STRUCTURE}

Williamson realized the taxonomic significance of wall structure. He was the first to appreciate that the organic membrane (seen after dissolving a test in dilute acid as originally described by Dujardin, 1835a) is a template upon which the calcareous shell was deposited (Williamson, 1847, p. 38). Thin sections of Polystomella crispa (=Elphidium crispum) were used to demonstrate that retral processes (which he called 'transverse undulations of each segment', Williamson, 1848b, p. 164) are tubular but that they end blindly against the septum. He also observed that the septa are two-layered because only one layer of septal wall is present at the blind ends of the septal processes. He noted that the umbilical regions become thickened with calcareous deposits during test growth, indicating that the soft parts must have covered them from time to time. He was the first to recognize layering of the wall in Amphistegina and 'Nonionina' and concluded that with the secretion of each chamber the new wall extends over most or all of the outermost whorl (Williamson, 1851 , p. 107) and that the soft parts must cover the whole test during this process. The canal system of Amphistegina and Operculina (which he called Nonionina) was interpreted to maintain communication between various parts of the test. He also drew attention to the fact that all foraminifera possess a 'central cell', i.e. a proloculus. He was critical of Ehrenberg's technique of examining all his material mounted in Canada balsam as he considered that it led to misleading observations (Williamson, 1848b, pp. 168-9). He also noted that Orbitolites complanata Lamarck, Marginopora and Peneroplis are imperforate and not layered (Williamson, 1851). Later (Williamson, 1858, p. xi) he defined the terms arenaceous (now often termed agglutinated), porcelainous (now termed porcelaneous) and hyaline.

\section{SPECIES CONCEPT}

There was also uncertainty over what constituted a species. Since most education had a strong religious element animals and plants 


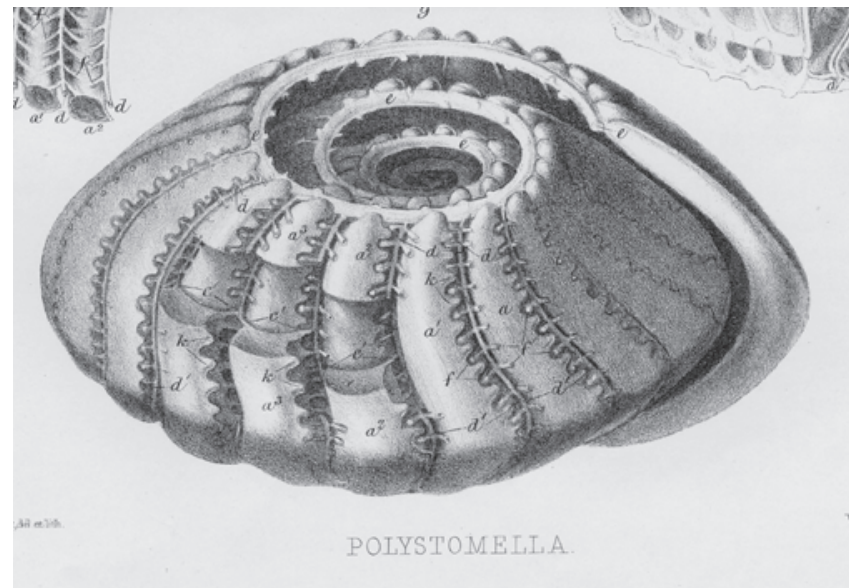

Fig. 4. The internal structures of the large tropical species 'Polystomella craticulata' (Fichtel \& Moll) now known as Elphidium craticulatus. In this preparation the test was infilled with an acid-resistant substance which set. Then the test wall was dissolved away. The drawing shows the shapes of the chambers, the retral processes and parts of the canal system. Test diameter 3.45 mm. Illustration from Carpenter (1862, pl. 16, fig. 9).

were considered to have been divinely created, although each species was known to show morphological variation. Parker wrote that a study of 'animal morphology leads to continually grander and more reverent views of creation and of a Creator' (see Jones \& Harting, 1890). There were profound differences between the approaches of English and European workers.

\section{CARPENTER'S VIEWS}

For Carpenter the fact that the soft parts were apparently the same in otherwise morphologically different forms led him to undervalue the hard parts of foraminifera as of taxonomic importance. As pointed out by Cifelli (1990), Carpenter's main contribution to taxonomy was his analysis of shell architecture and construction, internal structures and canal systems, based on the careful analysis of thin sections and casts (see Fig. 4). However, Carpenter believed variation to be so extreme that species could hardly be defined. He considered that 'sharply defined divisions - whether between species, genera, families, or orders - do not exist among Foraminifera' (Carpenter, 1862, p. vii). He still held the same view in 1885 (p. 101) when he wrote of Orbitolites 'if all genetic series were preserved, we should find no fixed boundary lines between species'. Also he considered the systematic division based on growth patterns between monothalamous (single-chambered) and polythalamous (multi-chambered) forms to be unnatural and the subdivision of the latter into orders based on growth plans to be wrong. He believed that the physiology of the organism and wall structure (which he termed 'texture') were more important taxonomic features. His collaborators (Parker \& Jones) were in agreement with him on these points. Later (Carpenter, 1862 , p. 42) he elaborated this point and it is clear that he regarded wall structure as more important than growth plan since the same plans occur in forms with different wall structures. By physiology he appears to refer to the observation that the soft parts of foraminifera are similar in all varieties and show no differentiation into specialized structures for feeding or locomotion. Nevertheless, he also attributed the high diversity of forms to be the result of modifications successively occurring in the course of descent from a small number of original types than to have originated in the vast number of distinct creations which on the ordinary hypothesis would be required to account for it (Carpenter, 1862, p. viii).

Furthermore, he considered that classification should be based on 'actual relationship arising from community of descent' (Carpenter, 1862, p. viii) and, following Ehrenberg, that a high proportion of modern foraminifera are direct descendants of those of the geological past. He also noted (correctly) that a greater range of variety (what is nowadays termed species diversity) exists at present than in previous times (Carpenter, 1862, p. xi). However, he also stated that 'there is no evidence of any fundamental modification or advance in Foraminiferous type from the Palaeozoic period to the present time' (Carpenter, 1862, p. xi). Carpenter's dismissal of species and his belief that species remained unchanged through long periods of geological time caused those interested in evolution to ignore the group for a long time (Lipps, 1981).

\section{WILLIAMSON'S VIEWS}

Although Williamson is perhaps best remembered for his 1858 monograph he was not by nature a taxonomist and he regarded species as showing a wide degree of morphological variation related to their age and environment: '... most of the external features on which both earlier and later writers relied for distinguishing their species, possess but little value (Williamson, 1858, p. ix):

I should rather infer that the hard shells of the Foraminifera do not constitute a sufficiently constant and important element in the organisation to justify our trusting them as guides in the discrimination of species. They appear to be a variable feature, like the hair amongst human beings, or the changing contours of a protean amoeba. (Williamson, 1858, p. x.)

He had written similar comments about gradations between species in his 1848a paper on Lagena. He also believed that fossil forms had long stratigraphic ranges (Williamson, 1865). Nevertheless, he was the first to formalize the terminology to describe the form and chamber arrangement of the test (Williamson, 1858, pp. xiv-xviii). Although he used the term septum he referred to chambers as 'segments'.

\section{INFLUENCE ON OTHER WORKERS}

Carpenter and Williamson's views on variability strongly influenced other British workers, such as Parker, Jones and Brady and established British workers as 'lumpers'. By contrast, d'Orbigny erected a large number of species ('splitter') and he believed that each species was a separate creation. He gave separate names to the same form occurring in different geographical areas and also to those separated from one another by strata (Heron-Allen, 1917; Le Calvez, 1974). Cifelli (1990) considers d'Orbigny to be the main spokesperson for Cuvier's catastrophism.

\section{INFLUENCE OF DARWIN'S ON THE ORIGIN OF SPECIES}

It was not until the publication of Darwin's On the Origin of Species in 1859 that an alternative to divine creation was put 
forward. Darwin showed not only that natural selection led to continual improvements in species but also that progressive evolutionary changes could give rise to new species. In his discussion of classification, Darwin noted that naturalists arrange species, genera, etc. in the Natural System based on their similarities and differences. He went on to state:

But many naturalists think that something more is meant by the Natural System; they believe that it reveals the plan of the Creator; but unless it be specified whether order in time or space, or both, or what is meant by the plan of the Creator, it seems to me that nothing is thus added to our knowledge (Darwin, 1859, p. 413).

Nevertheless, Carpenter (1883b; 1885) was a staunch believer of a plan by a Creator and used his studies of Orbitolites as a direct attack on Darwin's theory of evolution. In 1885 (p. 101) Carpenter wrote: 'I have always been one of those who could not accept the doctrine of "natural selection" as a verra causa'. One of his main concerns was 'what gives rise to variations?' and whether they were 'aimless' or followed a definite 'plan' (Carpenter, 1883 b, p. 569, and repeated in 1885). Because he believed that simpler forms gave rise to more complex forms, as in Orbitolites, yet simple and complex forms co-exist in the same environments, he concluded that none was fitter than another. Likewise predators would not be able to discriminate between species 'which even the trained eye of the naturalist cannot distinguish without the assistance of a magnifying glass' (Carpenter, 1883b, p. 570; similar comments in 1885). He concluded that there is no room for 'natural selection'. 'To my mind everything is indicative of development upon a determinate plan.' More than a century later we now realize that small morphological differences between species usually reflect differences of niche. Although two similar species may coexist in the same general environment they invariably have subtle preferences of food type, position in the sediment, etc. so that they are not necessarily directly competing with one another, each exploiting its own niche. Furthermore, it is virtually impossible for very small organisms to put up an effective defence against larger predators who are unselective in their feeding behaviour. Success is surviving long enough to reproduce.

\section{BRITISH RECENT FORAMINIFERA}

It was Williamson's intention to preface his 1858 monograph with '. . . a general history of this class of objects; reviewing the various modifications of their structure, their zoological affinities, and their geological history'. However, the Council of the Ray Society decided that these aspects should be more fully discussed than would be possible in a single monograph so they asked W. B. Carpenter to prepare a separate volume (Carpenter, 1862). No attempt was made to classify genera into suprageneric groups and all previous attempts were condemned as 'utterly worthless' (Williamson, 1858, p. xix). It seems clear that Williamson was overwhelmed by the morphological variety of foraminifera and by their abundance not only in modern sediments but also in the fossil record. It is not surprising that he was hesitant in his taxonomic treatment.

Nevertheless, the monograph contains descriptions and illustrations (hand-coloured) of many new species and varieties and remains an invaluable reference source. Most of his slides are housed in the Natural History Museum, London and all species are represented by syntypes.
Williamson (1858) introduced the terms 'hyaline' and 'arenaceous' and these were used by Parker \& Jones (1857, p. 274), but they wrote of 'opake and homogenous' shells which Williamson described as 'porcelainous' (Williamson, 1858, p. xi). Williamson also noted that no foraminifera with '... the same form of shell has indifferently presented the arenaceous, porcelainous, and hyaline textures'(Williamson, 1858, p. xii).

\section{THE ORIGIN OF LIMESTONES}

Prior to the Challenger Expedition of 1872-6, there was limited information on the distribution and composition of submarine sediments. The origin of limestones was uncertain and included both organic and inorganic alternatives. However, it had already been noted that some limestones are abundant in microscopic fossils. In his 1847 analysis of the subject, Williamson noted that many beach sands on English coasts, Florida, USA and the West Indies are composed largely of biogenic debris including foraminifera. He wrote 'It has long been known to geologists that in both the Adriatic and the Mediterranean a modern calcareous stratum is in the process of formation' (Williamson, 1847, p. 9). This paper set out to describe the microorganisms in 'Levant' mud based on material from somewhere to the east of Malta. He recorded foraminifera, diatoms and many different types of organisms. $\mathrm{He}$ had obviously also looked at a wide range of material both modern and fossil from numerous localities around the world, as well as reviewing the literature available. His overall conclusions were that most limestones are organic in origin and also that modern processes could explain the formation of rocks (in accordance with Lyell's (1837) views on uniformitarianism).

\section{SUMMARY}

The two key nineteenth century British workers on foraminifera, Williamson and Carpenter, were essentially gentleman microscopists who pursued their studies as a hobby. Between them they made notable contributions to understanding the morphology and structure of tests, including the recognition of different types of wall structure. However, they took a broad view of taxonomic relationships which strongly influenced later workers, such as Brady, Parker and Jones, and was in marked contrast to the ideas of contemporary European workers. Although Williamson was not primarily a taxonomist, he nevertheless laid the foundations of the naming of modern species from around Britain.

\section{ACKNOWLEDGEMENTS}

I thank the University of Southampton for continuing to providing facilities in my retirement. I also thank the staff of the libraries in the Natural History Museum, London for their help in tracking down obscure references and for the images in Figures 2 and 3 (for which they retain copyright). The Royal Society is thanked for permission to use the photograph of Carpenter (Fig. 1a). That of Williamson (Fig. 1b) is reproduced by courtesy of the University Librarian and Director, The John Rylands University Library, The University of Manchester, and a high-quality digital file was kindly supplied by Joan Watson.

\section{Manuscript received 06 December 2011 Manuscript accepted 20 January 2012 Scientific Editing by Alan Lord}




\section{APPENDIX A: NOTES ON OTHER BRITISH GENTLEMAN MICROSCOPISTS}

Robert Hooke (1635-1703): illustrated a single individual of 'Rotalia' (Hooke, 1665, fig. X, opposite p. 44) (Williamson, 1858, p. v; illustrated in Cifelli, 1990, fig. 1).

William Boys (1735-1803): a surgeon (and mayor in 1767 and 1782), Sandwich, Kent. Together with George Walker (a bookseller from Faversham, Kent) published descriptions of various small animals (Walker \& Boys, 1784) to which binomial nomenclature was applied by Walker (Williamson, 1858, pp. v, vi) and published with Edward Jacob (1710-1788) in 1798.

Colonel George Montagu (1753-1815): his main interest was ornithology but he was also a keen conchologist who described foraminifera from the south coast of England (Montagu, 1803; 1808). His annotated copy of this work is housed in the Linnean Society.

Professor William Macgillivray (1796-1852): Professor of Natural History at Marischal College, Aberdeen, from 1841. He was the first person to apply to British species the generic names of d'Orbigny and published the first record of a British Textularia (Williamson, 1858, p. vii) but regarded them as cephalopods (Macgillivray, 1843).

John Gwyn Jeffreys (1809-85): worked on foraminifera (manuscript offered to the Linnean Society in 1828 but not published) (for whom Nonionina jeffreysii was named by Williamson, 1858).

Thomas Rupert Jones (1819-1911): born in London. He studied medicine as an apprentice to surgeons in Taunton and Newbury (1835-42) and then practised in London. In 1849 he became assistant secretary to the Geological Society of London and in 1862 Professor of Geology at the Royal Military Academy, Sandhurst. He taught Parker about foraminifera and encouraged him to publish his results.

Professor William Kitchen Parker (1823-90): born at Dogsthorpe near Peterborough. He was described by Jones \& Harting (1890) as courteous and gentle, a nature lover, especially of birds and plants; he had no university education. At 15 he was apprenticed to a pharmacist and at 18 to a medical doctor. In 1849 became a Licentiate of Apothecaries. He was a medical practitioner in Pimlico, London, and later Hunterian Professor of Comparative Anatomy and Physiology at King's College, London. He was an expert on vertebrates and made major contributions to their understanding strongly influenced by his Christian faith. Williamson and Jones encouraged him to study the taxonomy of foraminifera and, with the latter, published a series of papers revising the taxonomy of recent species. He also worked with Carpenter and Brady. He believed that all species were divinely created (Jones and Harting, 1890; Murray, 1981).

Reverend Canon Alfred Merle Norman (1831-1918): his collection is in the Natural History Museum, London, but most of it does not relate to publications except as species lists. He was interested in agglutinated wall structures of foraminifera and annelids (Norman, 1878). He was also a major collector of molluscs.

Fortescue William Millett (1833-1915): a recluse with few friends beyond his local circle and an expert on west of England dialects. He published monographs of the Malay Archipelago
(Millett, 1898-1904) and Neogene St Erth Clays, Cornwall (Millett, 1886-1902; Sherborn, 1915; Murray, 1981).

Joseph Wright (1834-1923): a Quaker and grocer. He made contributions to Cretaceous, Quaternary and Recent foraminifera from around Ireland (Wilson, 1987).

Henry Bowman Brady (1835-91): a pharmacist who made significant contributions to the study of British Recent foraminifera and famed for his epic work on the foraminifera of the Challenger Expedition (see Jones, 1994, for a full account).

Edward Halkyard (1854-1917): born in Lancashire but ill-health necessitated trips to warmer climes during the winter. This led to studies of the Recent foraminifera of Jersey (Halkyard, 1889) and his posthumous work on the Eocene of Biarritz (Halkyard, 1919, edited by Heron-Allen and Earland and with biographical notes). His collection is in the Manchester Museum.

Edward Heron-Allen (1861-1943): a polymath in whose honour an appreciation society, the Heron-Allen Society, was established in 2000. It holds annual symposia on his life and work and publishes the talks in Opuscula (see www.nhm.ac.uk/ hosted_sites/heronallen/society.htm). For many years HeronAllen collaborated with Arthur Earland. Together they made major contributions, mainly taxonomic, to the study of Recent foraminifera. The genera Heronallenia Chapman \& Parr, 1931 and Heronallenita Seiglie \& Bermúdez, 1965 were erected in his honour. Heron-Allen donated his collections and library to the Natural History Museum, London where they are housed in the Heron-Allen Library in the Palaeontology Department.

Charles Davies Sherborn (1861-1942): was primarily a bibliographer of natural history but he also collaborated with T. R. Jones and F. Chapman on fossil foraminifera (Elliott, 1978). Photograph in Hiltermann (1958).

George W. Chaster (1863-1910): a physician in Southport, Lancashire. Published widely on molluscs, entomology and foraminifera (obituary, Chaster, 1911).

Frederick Chapman (1864-1943): born in England but spent most of his life in Australia where he made notable contributions to palaeontology. He published widely on British and Australian foraminifera and he was awarded numerous medals for this (Crespin, 1979). Photograph in Hiltermann (1958).

Arthur Earland (1866-1958): a civil servant who worked in the Post Office Savings Department from 1885 to 1926 when he retired through ill health although he did not die until 1958. Halkyard, whom he met through the Queckett Microscopical Club, encouraged him to look at foraminifera and further encouragement came from Lister, Millett, Wright and D'Arcy Thompson. Earland was described as having 'a keen interest and untiring industry' (Hedley, 1958, p. 1440). Earland was the person who introduced Heron-Allen to the study of modern foraminifera and for many years from 1907 to 1932 they collaborated on a wide range of projects. HeronAllen terminated the collaboration abruptly in 1932 and this effectively ended his scientific career, yet Earland continued his work. Earland wrote that they had few points in common (Earland had self-avowed 'contempt for regulations, precedents and authorities' (Hedley, 1958, p. 1440), whereas Heron-Allen enjoyed the more routine aspects of research (Earland, 1943)). Heron-Allen was described as vain and egotistic (Earland, 1943). The genera Earlandammina, 
Earlandia, Earlandinella and Earlandinita, several species and the mineral earlandite have been named after him (see Robinson \& Austin, 2001).

William Archibald Macfadyen (1893-1985): published short notes on Quaternary foraminifera.

\section{APPENDIX B: KEY COLLECTIONS:}

Carpenter: Royal Albert Memorial Museum, Exeter (Murray \& Taplin, 1984) and Natural History Museum, London.

Williamson: Natural History Museum, London.

Earland: privately owned.

Heron-Allen: Natural History Museum, London (Hodgkinson, 1989).

Millett: Natural History Museum, London.

Parker: Natural History Museum, London (Hodgkinson, 1992).

\section{BIBLIOGRAPHY OF FORAMINIFERAL WORKS BY CARPENTER}

Carpenter, W.B. 1849. On the microscopic structure of Nummulina, Orbitolites and Orbitoides. Quarterly Journal of the Geological Society of London, 6: 21-38.

Carpenter, W.B. 1856a. Researches on the foraminifera. Part 1. Containing general introduction, and monograph of the genus Orbitolites. Philosophical Transactions of the Royal Society, London, 146: 181-236.

Carpenter, W.B. 1856b. Researches on the foraminifera. Part 11. On the genera Orbiculina, Alveolina, Cycloclypeus and Heterostegina. Philosophical Transactions of the Royal Society, London, 146: 547-569.

Carpenter, W.B. 1860. Researches on the foraminifera. Part 111. Containing general introduction, and monograph of the genus Orbitolites. Philosophical Transactions of the Royal Society, London, 149(1859): 1-41.

Carpenter, W.B. 1861a. Researches on the foraminifera - fourth and concluding series. Philosophical Transactions of the Royal Society, London, 150(1860): 535-594.

Carpenter, W.B. 1861b. General results of the study of typical forms of foraminifera, in their relation to the systematic arrangement of that group, and to the fundamental principles of natural history classification. Natural History Review, 1: 185-201.

Carpenter, W.B. 1861c. On the systematic arrangement of the Rhizopoda. Natural History Review, 1: 456-472.

Carpenter, W.B. (assisted by Parker, W.K. \& Jones, T.R.) 1862. Introduction to the study of foraminifera. Ray Society, 319pp, pp. i-xxi, pls i-xxi.

Carpenter, W.B. 1868. Preliminary report of dredging operations in the seas to the north of the British islands, carried on in H.M.S. 'Lightning' by Dr Carpenter and Dr Wyville Thomson. Proceedings of the Royal Society, London, 17: 168-197.

Carpenter, W.B. 1869. On the rhizopodal fauna of the deep sea. Annals and Magazine of Natural History, ser. 4, 22: 287-290.

Carpenter, W.B. 1870a. Descriptive catalogue of objects from deep-sea dredgings. W. Clowes and Sons, London, $11 \mathrm{pp}$.

Carpenter, W.B. 1870b. On the shell-structure of Fusulina. Monthly Microscopical Journal, 3: 180-182.

Carpenter, W.B. 1875a. The microscope and its revelations, 5th edn. Lindsay and Blakiston, Philadelphia, chapter 10: 514-562.

Carpenter, W.B. 1875b. Remarks on Professor Wyville Thomson's preliminary notes on the nature of the sea bottom procured by soundings of H.M.S. 'Challenger'. Proceedings of the Royal Society, London, 23: 234-245.

Carpenter, W.B. 1876a. Remarks on Mr Carter's paper 'On the Polytremata, especially with reference to their mythical hybrid nature'. Annals and Magazine of Natural History, ser. 4, 17: 380-387.
Carpenter, W.B. 1876b. On the genus Astrorhiza of Sandahl, lately described as Haeckelina by $\operatorname{Dr}$ Bessels. Quarterly Journal of Microscopical Science, n.s., 16, 221-224.

Carpenter, W.B. 1877. Foraminifera. In Jeffreys, J.G., Preliminary Report of the biological results of a cruise in H.M.S. 'Valorus' to Davis Strait in 1875. Proceedings of the Royal Society, London, 25: 223-227.

Carpenter, W.B. 1881. The microscope and its revelations, 6th edn. Ballantyne, Henson and Co., London, chapter 12: 543-595.

Carpenter, W.B. 1883a. Report on the specimens of the genus Orbitolites collected by H.M.S. 'Challenger' during the years 1873-1876. Report of the Voyage of the Challenger, Zoology, 7, pt 21, art. 4: 1-47.

Carpenter, W.B. 1883b. Researches on the foraminifera. Supplemental Memoir. On an abyssal type of the genus Orbitolites: a study in the theory of descent. Philosophical Transactions of the Royal Society, London, 174: 551-573.

Carpenter, W.B. 1885. On the structure of Orbitolites. Journal of the Queckett Microscopical Club, 2: 91-103.

Carpenter, W.B. 1900. Foraminifera. In Kellogg, D.O. (Ed.), Encyclopedia Britannica, 9th edn. Werner and Co. New York, 9: 371-387.

Carpenter, W.B. \& Brady, H.B. 1870. Description of Parkeria and Loftusia, two gigantic types of arenaceous foraminifera. Philosophical Transactions of the Royal Society, London, 159: 721-754.

Carpenter, W.B. \& Jeffreys, G. 1871. Report on deep-sea researches carried on during the months of July, August and September, 1870, in H.H. Surveying-ship 'Porcupine'. Proceedings of the Royal Society, London, 19: 146-221.

Carpenter, W.B., Jeffreys, G. \& Thomson, W. 1870. Preliminary report of the scientific exploration of the deep sea in H.H. Surveying-vessel 'Porcupine', during the summer of 1869. Proceedings of the Royal Society, London, 18: 397-453.

\section{BIBLIOGRAPHY OF FORAMINIFERAL WORKS BY WILLIAMSON}

Williamson, W.C. 1847. On some microscopical objects found in the mud of the Levant and other deposits, with remarks on the mode of formation of calcareous and infusorial siliceous rocks. Manchester Philosophical Society, Memoir 6: 1-128.

Williamson, W.C. 1848a. On the recent species of the genus Lagena. Annals and Magazine of Natural History, ser. 2, 1: 1-20.

Williamson, W.C. $1848 \mathrm{~b}$. On the structure of the shell and soft animal of Polystomella crispa; with some remarks on the zoological position of the foraminifera. Transactions of the Microscopical Society, 2: 159-180.

Williamson, W.C. 1851. On the minute structure of the calcareous shells of some recent species of foraminifera. Transactions of the Microscopical Society, 3: 105-128.

Williamson, W.C. 1853. On the minute structure of a species of Faujasina. Quarterly Journal of Microscopical Science, 1: 87-92.

Williamson, W.C. 1858. On the recent foraminifera of Great Britain. Ray Society, $\mathrm{i}-\mathrm{xx}+1-107 \mathrm{pp}$.

Williamson, W.C. 1865. On the anatomy and physiology of the foraminifera. Popular Science Review, 4: 171-179.

Williamson, W.C. 1876. Corrections of the nomenclature of the objects figured in a memoir 'On some of the minute objects found in the mud of the Levant'. Manchester Literary and Philosophical Society, Memoir 25: 131-136.

\section{REFERENCES}

Bartenstein, H. 1964. Ludwig Rhumbler. Paläontologische Zeitschrift, 38: 223-226.

Chaster, G.W. 1911. Obituary. Irish Naturalist, 19: 137.

Cifelli, R. 1990. A history of classification of foraminifera (1826-1933) Part 1. Foraminiferal classification from d'Orbigby to Galloway. Cushman Foundation for Foraminiferal Research, Special Publication, 27: 1-88. 
Corfield, R. 2004. The Silent Landscape. In the Wake of HMS Challenger 1972-1876. John Murray, London, 285pp.

Corliss, J.O. 1978. A salute to fifty-four great microscopists of the past, a pictorial footnote to the history of protozoology Parts I \& II. Transactions of the American Microscopical Society, 97: 419-458.

Crespin, I. 1979. Chapman, Frederick (1864-1943). Australian Dictionary of Biography, Volume 7. Melbourne University Press, Australia, 612pp.

Darwin, C. 1859. On the Origin of Species. John Murray, London, 502pp.

Dujardin, F. 1835a. Observations nouvelles sur les Céphalopodes microscopiques. Annales des Sciences Naturelles, ser. 2, 3: 108-109.

Dujardin, F. 1835b. Observations nouvelles sur les prétendus Céphalopodes microscopiques. Annales des Sciences Naturelles, ser. 2, 3: 312-314.

Dujardin, F. 1835c. Observations sur les Rhizopodes et les Infusoires. Comptes Rendus de l'Academie des Sciences, 338-340.

Dujardin, F. 1835d. Recherches sur les Organismes Inférieures. Annales des Sciences Naturelles, ser. 2, 4: 343-377.

Earland, A. 1943. Edward Heron-Allen, F.R.S. Journal of the Royal Microscopical Society, 63(3): 48-50.

Ehrenberg, C.G. 1838. Über dem blossen Auge unsichtbare Kalkthierchen und Kieselthierchen als Hauptbestandtheile der Kreidegebirge. Bericht über die zur Bekanntmachung geeigneten Verhandlungen der Königlichen Preussischen Akademie der Wissenschaften zu Berlin, 192-200.

Ehrenberg, C.G. 1839 [published 1840]. Über die Bildung der Kreidefelsen und des Kreidermergels durch unsichtbare Organismen. Physikalische Abhandlungen der Königlichen Akademie der Wissenschaften zu Berlin, 59-147.

Elliott, G.F. 1978. Charles Davies Sherborn, 1861-1942, an appreciation. In Hedley, R.H. \& Adams, C.G. (Eds), Foraminifera, 3: 267-273.

Gervais, P. 1847. Sur un point de la Physiologie des Foraminifères. Comptes rendus hebdomadaires de l'Académie des Sciences, 25: 467-468.

Halkyard, E. 1889. Recent foraminifera of Jersey. Transactions of the Manchester Microscopical Society, 55-72.

Halkyard, E. 1919. The fossil foraminifera of the Blue Marl of the Côtes des Basques, Biarritz. Memoirs and Proceedings of the Manchester Literary and Philosophical Society (1918), 62(2): 1-145.

Hedley, R.H. 1958. Mr Arthur Earland. Nature, 181: 1440-1441.

Heron-Allen, E. 1917. Presidential Address. Alcide d'Orbigny, his life and work. Royal Microscopical Society, 1-105.

Hiltermann, H. 1958. Aus der Geschichte der angewandten Mikropaläontologie. Handbuch der Mikroskopie in der Technik, Band II, Teil 3, Mikroskopie in der Geologie sedimentäre Lagerstäten (Mikropaläontologie), 3-12.

Hodgkinson, R.L. 1989. The Heron-Allen \& Earland type slide collection of foraminifera in the British Museum (Natural History). Journal of Micropalaeontology, 8: 149-156.

Hodgkinson, R.L. 1992. W.K. Parker's collection of foraminifera in the British Museum (Natural History). Bulletin British Museum of Natural History (Geology), 48(2): 45-78.

Hooke, R. 1665. Micrographia Illustrata. John Martyn \& James Allestry, London, 255pp. Facsimile reprint, Impression Anastaltique, Culture et Civilisation, Brussels, 1966.
Jones, R.W. 1994. The Challenger Foraminifera. The Natural History Museum, London and Oxford University Press, Oxford, 151pp.

Jones, T.R. \& Harting, J.E. 1890. William Kitchen Parker. Proceedings of the Royal Society, London, 48: xv-xx.

Le Calvez, Y. 1974. Great names in micropalaeontology 1. Alcide d'Orbigny. In Hedley, R.H. \& Adams, C.G. (Eds), Foraminifera, 1: 261-264.

Lipps, J.H. 1981. What if anything is micropaleontology. Paleobiology, 7: $167-199$.

Lyell, C. 1837. Principles of Geology: being an enquiry how far former changes of the earth's surface are referable to causes now in operation, 5th edn. John Murray, London, 462pp.

Macgillivray, W. 1843. A history of the Molluscous animals of Aberdeen, Kincardine and Banff. Cunningham and Mortimer, London, 372pp.

Millett, F.W. 1886-1902. Notes on the fossil foraminifera of the St Erth clay pits. Transactions of the Royal Geological Society of Cornwall, in 6 parts.

Millett, F.W. 1898-1904. Report on the Recent Foraminifera of the Malay Archipelago. Journal of the Royal Microscopical Society, in 17 parts.

Montagu, G. 1803. Testacea Britannica, or natural history of British shells marine, land and freshwater, including the most minute. J.S. Hollis, Romsey, England, 606pp.

Montagu, G. 1808. Testacea Britannica, Supplement. S. Woolmer, Exeter, England, 183pp.

Murray, 1981. Some early students of foraminifera in Britain. In Jenkins, D.G. \& Murray, J.W. (Eds), Stratigraphical Atlas of Fossil Foraminifera. Ellis Horwood, Chichester, 9-12.

Murray, J.W. \& Taplin, C.M. 1984. The W.B. Carpenter collection of foraminifera: a catalogue. Journal of Micropalaeontology, 3: 55-58.

Norman, A.M. 1878. On the genus Halyphysema, with a description of several forms apparently allied to it. Annals and Magazine of Natural History, ser. 5, 1: 265-287.

Orbigny, A.d' 1826. Tableau Méthodique de la classe des Céphalopodes. Annales des Sciences Naturelles, 7: 245-314.

Parker, W.K. \& Jones, T.R. 1857. Description of some foraminifera from the coast of Norway. Annals and Magazine of Natural History, ser. 2, 19: $273-303$.

Robinson, M. \& Austin, W.E.N. 2001. Arthur Earland, the foraminiferal slide collection and correspondence at the University of St Andrews, Scotland. Journal of Micropalaeontology, 20: 97-122.

Sherborn, C.D. 1915. Fortescue William Millett. Geological Magazine (6), 11: 288.

Walker, G. \& Boys, W. 1784. Testacea minuta variora, nuperrime detecta in arena littoris Sandivicensis. J. March, London, 25pp.

Walker, G. \& Jacob, E. 1798. In Adam's essays on the microscope. W \& S Jones, London, 2nd edn, revised by Kanmacher, F., 629-642, pl. xiv, figs 2-6, 10-12, 29-38.

Watson, J. \& Thomas, B.A. (Eds) 1985. Reminiscences of a Yorkshire Naturalist, by W.C. Williamson, facsimile edition, 228pp.

Wilson, J. 1987. Joseph Wright, F.G.S., 1834-1923. The Irish Naturalists' Journal, 22: 169-180. 


\section{BiotecMicroslides}

Little Lower Ease

Cuckfield Road

ANSTY

West Sussex RH17 5AL

England

Tel/Fax: $\quad+44$ (0)1444 452282

Email: sales@biotecmicroslides.co.uk

Web: www.biotecmicroslides.co.uk

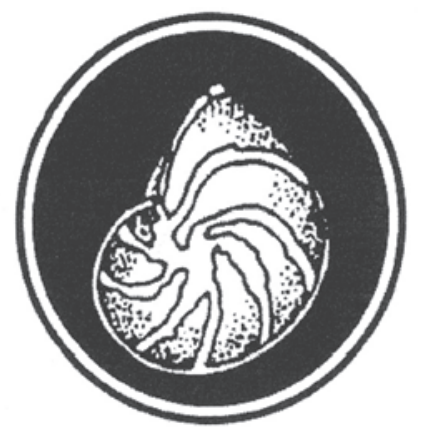

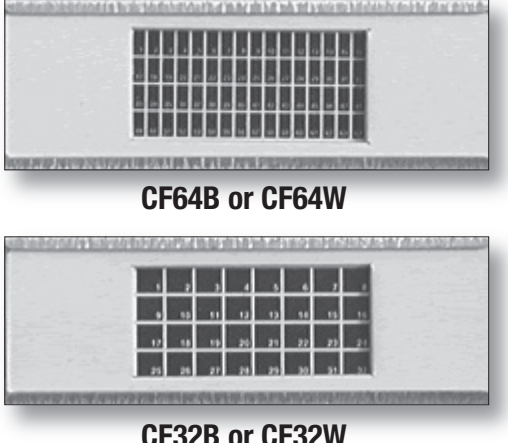

CF32B or CF32W

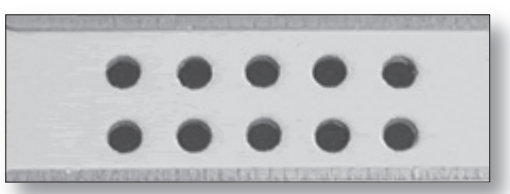

C10B or C10W
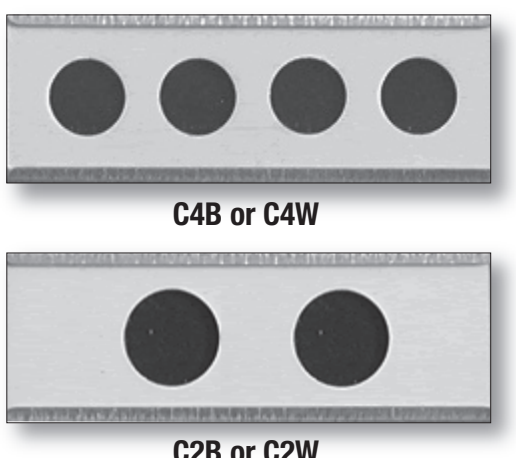

C2B or C2W

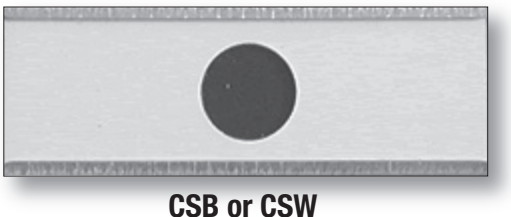

CSB or CSW

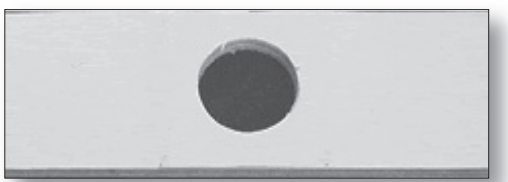

CSBDD or CSWDD
BiotecMicroslides has been manufacturing slides for the storage of microfossils and small zoological and botanical specimens since 1974 .

Slides, with either black or white cell backgrounds are available in cardboard with aluminium holder and glass coverslide. Also available to order are double-depth single-cell slides with paper tops and either acetate or glass coverslip.

Slide dimensions 3" x 1" (76mm x 27mm)

- Pine Storage Cabinets (28 drawers) with or without glazed door

- Picking trays $3 \frac{3 / 4}{4} \times 3 \frac{1}{4}$

$(97 \mathrm{~mm} \times 84 \mathrm{~mm})$

- 00 Picking brushes with sable or synthetic bristles 